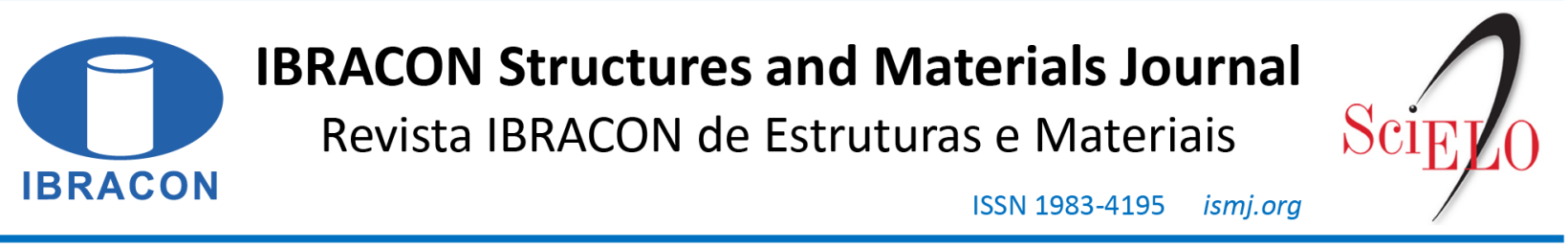

ORIGINAL ARTICLE

\title{
Elaboration of fracture prediction map using 2D digital image correlation - 2D CID
}

\section{Elaboração de mapa de previsão de fratura utilizando correlação de imagens digital 2D - CID 2D}

\author{
Leandro Silva de Assis ${ }^{\mathrm{a}}$ \\ Joaquim Teixeira de Assis ${ }^{\mathrm{b}}$ \\ José Renato de Castro Pessoa ${ }^{\mathrm{c}}$ (D) \\ Armando Dias Tavares Júnior ${ }^{\mathrm{d}}$
}

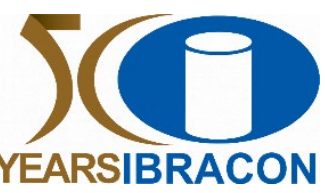

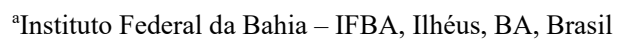

bLaboratório de Ensaios Físicos - LEFI, Instituto Politécnico do Rio de Janeiro / Universidade do Estado do Rio de Janeiro, Nova Friburgo, RJ,

Brasil

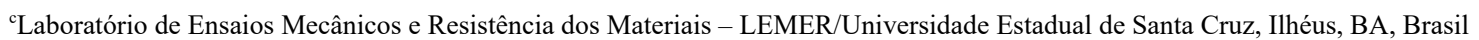

${ }^{\mathrm{d}}$ Laboratório de Ótica do Instituto de Física Armando Dias Tavares - IFADT/Universidade do Estado do Rio de Janeiro, Rio de Janeiro, RJ, Brasil

Received 06 September 2021

Accepted 10 November 2021

\begin{abstract}
This work aims to present a methodology for the elaboration of a deformation map in a Portland cement concrete specimen to predict fractures caused by axial compression stresses, using the technique of Digital Image Correlation - DIC 2D. For this purpose, 5 concrete specimens with compressive strength expected at 28 days fck of 40 MPa were analyzed, which were tested in the ABNT NBR 5739/2018 standard - compression test of cylindrical concrete specimens. During the test, the necessary digital images were acquired in the DIC-2D array. These images were subsequently processed, and the results interpreted statistically. According to the result of the correlation of images obtained, it was found that $67 \%$ of the specimens had regions of accumulation of stresses that indicated in advance the location of the rupture, which enabled the development of a fracture prediction map. The results obtained in the research showed that the methodology used by means of the DIC-2D arrangement was able to predict the place where the rupture in the specimens occurred.
\end{abstract}

Keywords: fracture, deformation, concrete, image.

Resumo: Este trabalho tem como objetivo apresentar uma metodologia para elaboração de um mapa de deformação em um corpo de prova de concreto de cimento Portland de modo a prever fraturas provocadas por tensão de compressão axial, utilizando técnica de Correlação Digital de Imagem - CID 2D. Para alcançar este objetivo, foram analisados 5 corpos de prova de concreto com resistência à compressão esperada aos 28 dias fck de $40 \mathrm{MPa}$ que foram ensaiados por meio da norma da ABNT NBR 5739/2018 - ensaio de compressão de corpos de prova cilíndricos de concreto. Durante o ensaio foram adquiridas as imagens digitais necessárias no arranjo CID-2D. Posteriormente essas imagens foram processadas e os resultados interpretados estatisticamente. De acordo com o resultado de correlação de imagens obtido, constatou-se que $67 \%$ dos corpos de prova possuíam regiões acumuladoras de tensão que indicaram antecipadamente o local da ruptura, o que permitiu a elaboração de um mapa de previsão de fratura. Os resultados obtidos na pesquisa mostraram que a metodologia utilizada por meio do arranjo CID-2D conseguiu prever o local onde houve ruptura no corpo de prova.

Palavras-chave: fratura, deformação, concreto, imagem.

How to cite: L. S. Assis, J. T. Assis, J. R. C. Pessoa, and A. D. Tavares Jr."Elaboration of fracture prediction map using 2D digital image correlation - 2D CID," Rev. IBRACON Estrut. Mater., vol. 15, no. 4, e15403, 2022, https://doi.org/10.1590/S1983-41952022000400003

Corresponding author: Leandro Silva de Assis. E-mail: leandro.assis@ifba.edu.br

Financial support: None.

Conflict of interest: Nothing to declare.

Data Availability: The data that support the findings of this study are available from the corresponding author, LSA, upon reasonable request. 


\section{INTRODUCTION}

The use of concrete in habitable constructions imply the need for rigorous processes to monitor the integrity of the structure, in particular eventual flaws that may lead to collapse [01], [02].

The microstructure of the concrete is heterogeneous and complex, making it difficult to develop realistic models of its microstructure that predict its behavior when deformed. This microstructure explains the great difference in values of tensile and compressive strength. [03]

One of the techniques that aid the interpretation and decision making with automatic analysis by computers is called DIC - 2D - Digital Image Correlation. The evolution of computers and improvement in the resolutions of digital cameras, made possible the analysis and quantification of small displacements caused by different stress levels from the overlapping of images [04], [05].

Thus, it is possible to map defects in concrete structures in service without necessarily having contact with them, facilitating the inspection of difficult-to-access structures with greater precision. [06]

According to Metha \& Monteiro [03], the strength of the concrete is associated with the movement of macropores inside the hardened paste, which start in capillary voids greater than $50 \mathrm{\eta m}$, reaching its fracture with displacements in the order of $2000 \mu \mathrm{m}$.

Considering that the tests used in diagnostic engineering are mostly limited to the heterogeneous condition of the concrete, and the human eye lower limit of accuracy in the order of $200 \mu \mathrm{m}$ when in its perfect's faculties, in addition to being subject to gross errors of reading and interpretation [07]. The revolution of digital images has boosted the possibilities of observation bringing with it resolutions that can reach $20 \mu \mathrm{m} /$ pixel, and when associated with computational algorithms, they become a powerful tool combined with non-destructive diagnostic engineering. [08]

This work presents a methodology to the elaboration of a deformation map in a Portland cement concrete specimen to predict fractures caused by axial compression loading, using DIC - 2D technique.

The following steps were performed to the analyses:

i) Relevant characteristics for the acquisition / manufacture of the specimen were evaluated for proper application in the DIC - 2D test and representation of a structure in service;

ii) Parameters of the DIC - 2D arrangement were defined for the acquisition of digital images with a resolution compatible with the displacements to be measured;

iii) The deformation of the specimen was analyzed using digital image correlation algorithms that process the images of the specimens acquired by the DIC - 2D arrangement;

vi) A deformation map was elaborated and superimposed on the digital image of the specimen to check if the occurrence of the crack matches the prediction found in the DIC - 2D.

\section{MATERIALS AND EXPERIMENTAL PROGRAM}

\subsection{Preparation of the specimens}

Five 10x20 cm cylindrical concrete specimens were modeled according to ABNT NBR 5738/2015 [09], using type CP V Portland cement, washed sand, and gravel 1, with an expected compressive strength of $40 \mathrm{MPa}$, according to the mix proportion shown in Table 1.

Table. 1 - Mix proportion of the concrete

\begin{tabular}{ccccc}
\hline CEMENT \% & FINE AGGREGATE\% & $\begin{array}{c}\text { COARSE } \\
\text { AGGREGATE\% }\end{array}$ & SLUMP (cm) & W/C \\
\hline 1 & 1.7 & 1.27 & 3.04 & 0.36 \\
\hline
\end{tabular}

After 24 hours the specimens were unmolded and kept in an immersion tank for 28 days to perform the wet cure and then removed and dried at an ambient temperature of approximately $25^{\circ} \mathrm{C}$, protected from direct sunlight.

Before tested to compression, the specimens were rectified. A lateral strip area of $8.5 \mathrm{~cm}$ in width and $20 \mathrm{~cm}$ in length, received superficial treatment.

The superficial treatment consisted of, spraying a matte black spray paint forming a stochastic pattern (speckle). In the respective strip, powdered flowering pigment with a particle size ranging from $10-60 \mu \mathrm{m}$ was applied, formed by inorganic compounds based on natural mica and metallic oxides of iron and titanium, according to the manufacturer's 
information (company MASTERBATCH PIGMENTOS). This pigment can emit brightness when illuminated with ultraviolet (UV) radiation [10], helping the digital correlation, as seen in the Figure 1a, b.
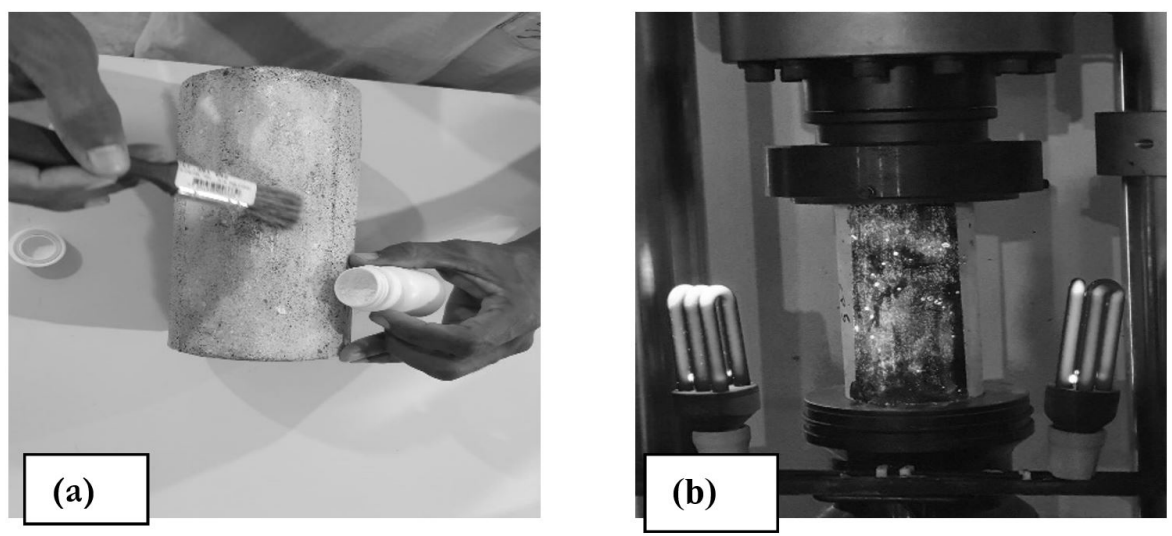

Figure 1: a) application of the contrast with flourishing powder b) Enhancement of the contrast with UV light [11]

\subsection{Mechanical test}

Each specimen was submitted to the axial compression loading according to NBR 5739/2018 [12], in a universal mechanical testing machine / model EMIC / PC200, applying progressive load at a constant rate of $0.5 \mathrm{MPa} / \mathrm{s}$, until failure.

\subsection{Acquisition of images in the 2D DIC array}

The images were acquired by a DIC - 2D arrangement, composed of: (a) a load application system capable of causing deformation in the specimen due to the axial compression load, (b) a set of artificial lighting in which two $27 \mathrm{~W}$ UV lamps are used to prevent shadows in the image, and, (c) a Canon / EOS model 70D digital camera with 18 - 55 $\mathrm{mm}$ lens, mounted on a tripod at a distance of $1.0 \mathrm{~m}$ from the target for which it formed an angle of $90^{\circ}$ with center line of the specimen.

The sensor was connected to a I5 laptop, 2.7Ghz, 4GB of RAM, as shown in Figure 2, which shows the DIC - 2D array assembled in the laboratory.

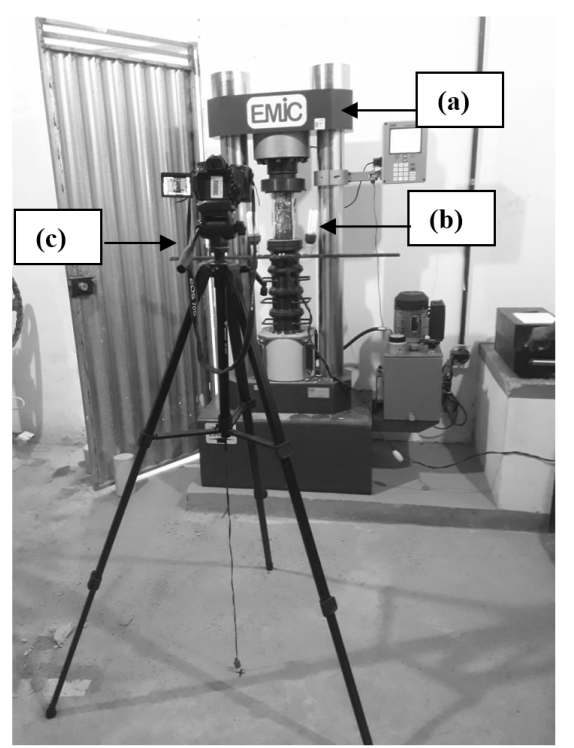

Figure 2: Assembly of the DIC-2D System a) load application system b) UV lamps c) a sensor digital camera [11] 


\subsection{Processing of images}

The acquired images were processed at NCORR, a set of algorithms developed by the Technological Institute of

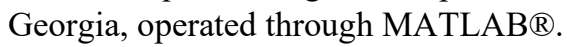

The initial image is divided into two sections called blocks or subsets of 10 pixels in radius and spacing between them by 2 pixels and these blocks are searched for in the next image. (Figure 3 )

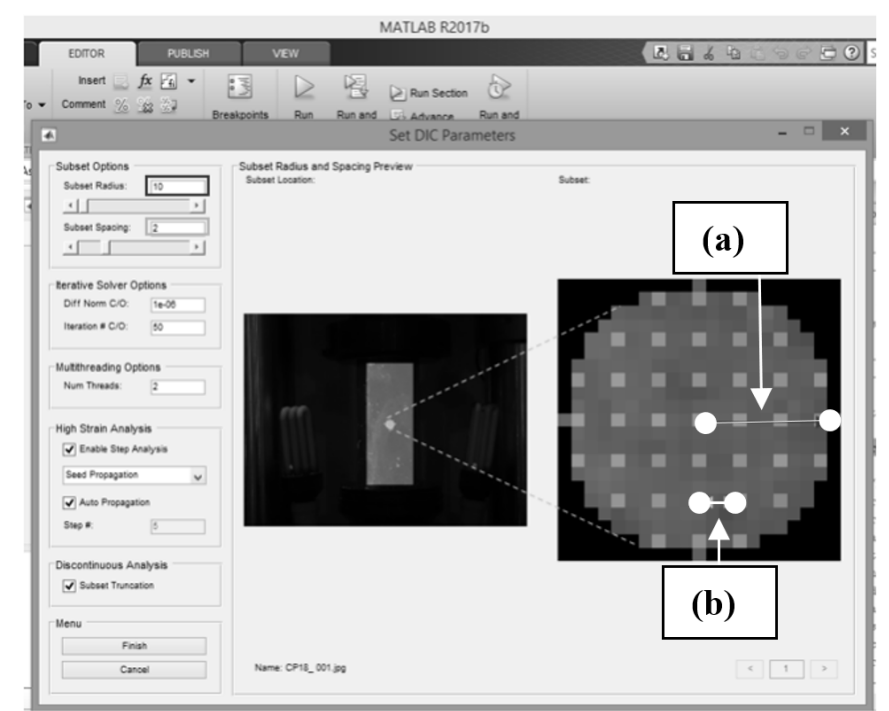

Figure 3: subsets of the region of interest (a) radius of the subset 10 pixels, (b) spacing of the subset 2 pixels [11]

Each block is a set of pixels and the objective of the algorithm is to determine its new position through the normalized cross-correlation cost function NCC (Eq. 1) [13], which indicates the closest likelihood, when analysing the intensity values of these pixels. The algorithm calculates the movement that the block made from one configuration to another, within an area (which is the search area of the algorithm) called Region of Interest (ROI), thus obtaining the displacements and, through these, later calculates the stresses [14].

$N C C=1-\frac{\sum_{i=1}^{N} \sum_{j=1}^{N} f_{i j} g_{i j}}{\sqrt{\sum_{i=1}^{N} \sum_{j=1}^{N} f i j^{2}-\sum_{i=1}^{N} \sum_{j=1}^{N} g i j^{2}}}$

Where:

NCC $=$ Normalized cross-correlation cost function

$\sum_{i=1}^{N} \quad=$ Sum of intensities in the reference image

$\sum_{j=1}^{N} \quad=$ Sum of intensity in the deformed image

$f_{i j} g_{i j}=$ Likelihood function operators $\mathrm{f}$ (reference image) $\mathrm{g}$ (deformed image)

$\sqrt{\sum_{i=1}^{N} \sum_{j=1}^{N} f i j^{2}-\sum_{i=1}^{N} \sum_{j=1}^{N} g i j^{2}}=$ Distance between operators in the reference image and the deformed image

\subsection{Propagation of Displacement and Deformation Fields}

To assist in the evaluation of deformations in the specimens, the images were divided into quadrants and subquadrants, as shown in Figure 4, in order to observe the position where the maximum and minimum values of the displacements occurred, enabling the mapping of the trajectory of the fractures while increasing loading. 

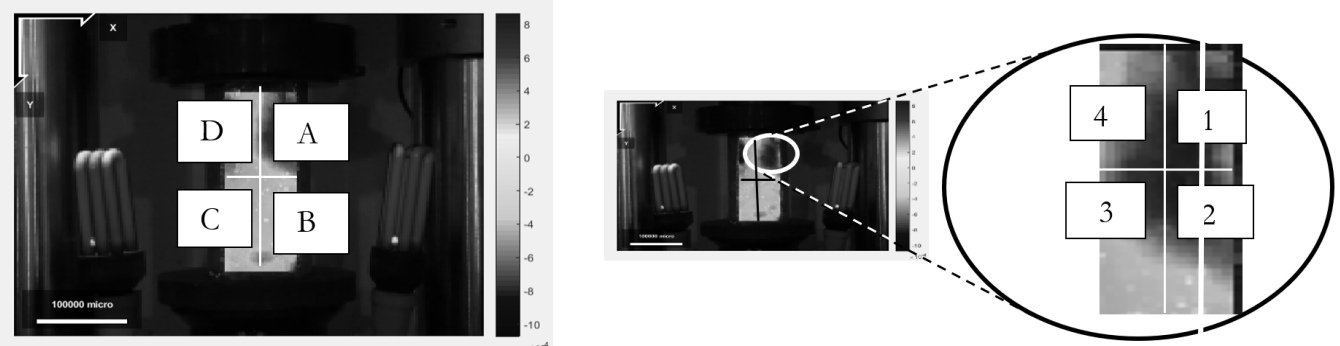

Figure 4 - Indication of quadrants A, B, C, D - Quadrants, 1,2,3,4 - Sub-squares [11]

\section{RESULTS AND DISCUSSIONS}

From the methodology represented in Figure 4, the map shown in Figure 5 was developed, which describes the location where the largest and smallest deformations occurred, evidencing the recurrent changes in direction in the fracture propagation front, as the load increased.
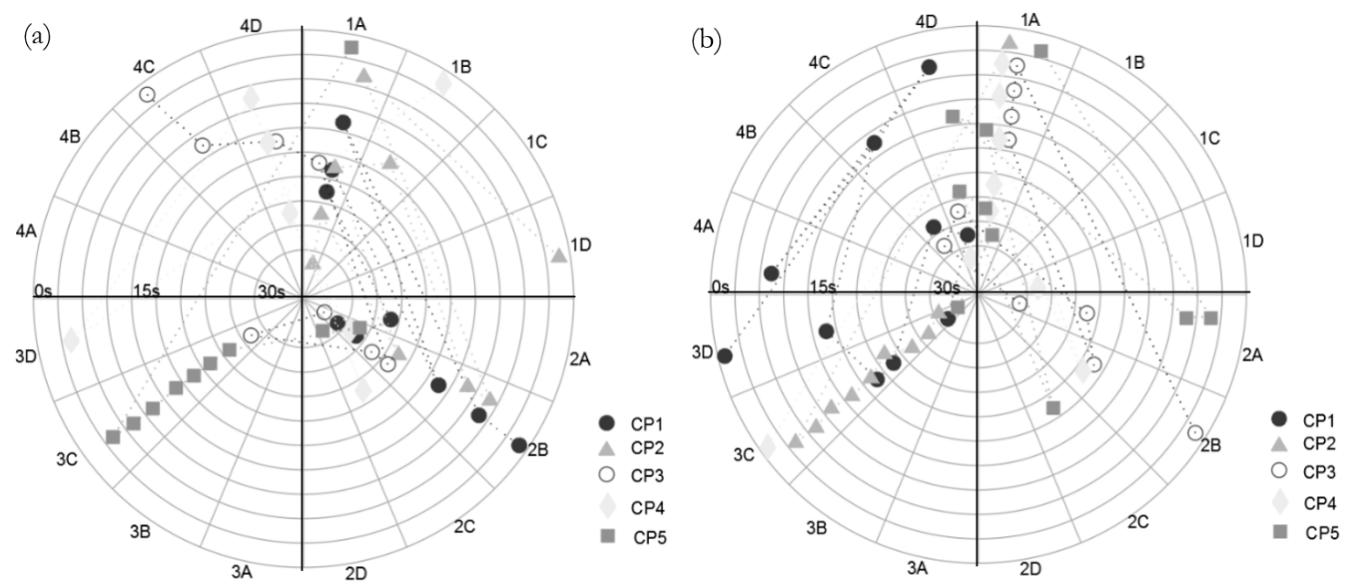

Figure 5 - Graphic map - a) spatial occurrence of maximum deformation on the $\mathrm{x}$ axis, b) spatial occurrence of minimum deformation on the $\mathrm{x}$ axis [11]

The concentric circles in graph represent the time (30s before the interval), decreasing from the center to the edges (time 30s in the center, less load and time $0 \mathrm{~s}$ on the edge, greater load), that is, they were compared with the reference image (without deformation). All images acquired with loading in relation to $30 \mathrm{~s}, 27 \mathrm{~s}, 24 \mathrm{~s}, 21 \mathrm{~s}, 18 \mathrm{~s}, 15 \mathrm{~s}, 12 \mathrm{~s}, 9 \mathrm{~s}, 6 \mathrm{~s}$, $3 \mathrm{~s}, 0 \mathrm{~s}$, where $30 \mathrm{~s}$ corresponds to the lowest deformation load and $0 \mathrm{~s}$ corresponds to the maximum deformation load in the ultimate limit state (rupture).

The orthogonal lines, represent the quadrants of the specimen, while the consecutive lines that cut the origin, represent the sub-squares, as indicated in the methodology (Figure 4).

The dotted lines indicate the trajectory of the deformation perceived by the proposed image correlation methodology for fracture prediction.

The distribution of the deformations presented by the map / graph (Figure 5a, b) suggests a non-linearity in the concrete deformation, and the main fracture propagation front can change its location when it finds stress concentrators, associated with fragility points in other regions of the studied PC, as stated by Corr [15].

To clarify the information brought by the maps / graphs, we highlight CP4, to make a detailed analysis of the occurrences of the displacement fields and their deformations in the $\mathrm{x}$ axis. 


\subsection{Exclusive deformation signature}

When analyzing the relative deformations on the x-axis, of CP4 in Figure 5a, it can be seen that the frequency of occurrence of the maximum deformation values was concentrated in the region between the 1st and 4th quadrant, however when observing the frequency of occurrence of the minimum values Figure $4 \mathrm{~b}$, a change of direction is observed for the 3rd quadrant, suggesting the regions of CP4, which will suffer stress relief, possibly with crack propagation.

In a general analysis of Figure 5a, b, it is observed that each specimen has a different design of the regions of occurrence of the maximum and minimum values of deformation, suggesting that the property of heterogeneous and non-linear concrete determines an exclusive deformation signature. Depending on the studies by Metha and Monteiro [03], which indicate the difficulty in developing models that describe this behavior in concrete. The elaboration of a fracture prediction map can prove experimentally the complexity of the specimen deformation.

\subsection{XY interdependence - POISSON coefficient}

When statistically observing the deformation planes $\varepsilon_{\mathrm{x}}$ and $\varepsilon_{\mathrm{y}}$, the Chi-square test revealed the interdependence of these variables with 95\% significance, when accepting the H0 hypothesis (Figure 6 and Table 2), suggesting that the deformation in the $\mathrm{x}$ plane is dependent on the deformation in the y plane, according to the Poisson's ratio cited by Araújo [16].

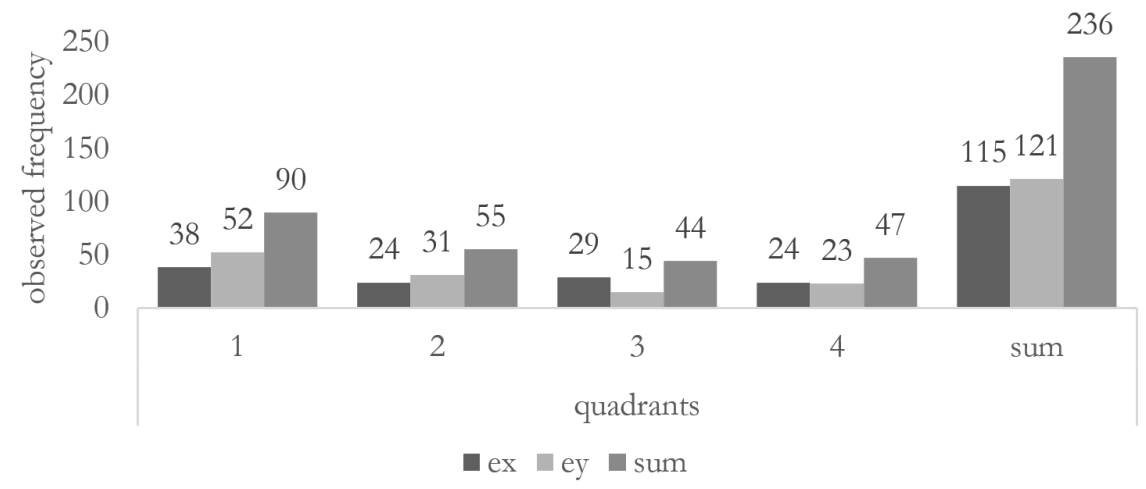

Figure 6 - Observed frequency of deformation $\varepsilon_{\mathrm{x}}$ and $\varepsilon_{\mathrm{y}}$ by quadrants.

Table 2 - On the left, deformation frequency $\varepsilon_{x}$ and $\varepsilon_{y}$ by quadrants A, B, C and D, on the right the parameters ANOVA, $\mathrm{X}^{2}$ standard deviation, G.L - degree of freedom, H0 - chi-square hypothesis.

\begin{tabular}{cccccc} 
& \multicolumn{3}{c}{ Quadrants } & & $\mathrm{X}^{2}=7.40$ \\
& $\mathrm{~A}$ & $\mathrm{~B}$ & $\mathrm{C}$ & $\mathrm{D}$ & $\mathrm{G} . \mathrm{L}=3$ \\
$\varepsilon \mathrm{x}$ & 38 & 24 & 29 & 24 & error $=5 \%$ \\
$\varepsilon \mathrm{y}$ & 52 & 31 & 15 & 23 & Critical value $=7.82$ \\
& & & & & H0 $=$ Acepted
\end{tabular}

\subsection{Fracture prediction map}

According to Mascia [17] the largest deformations are expected in the direction perpendicular to the application of the force, which for this experiment of axial compression test, it was observed that the largest deformations were perceived along the $x$ axis, which in fact was observed. By superimposing in the images, the frequency of the maximum and minimum values of deformation of the x-axis, according to its quadrant of occurrence extracted from the map / graph, the indication of the places of beginning of possible fractures, with magnitudes of $800 \mu \mathrm{m}$, was observed, according to the scale of the image acquired in the test. (Table 2) 


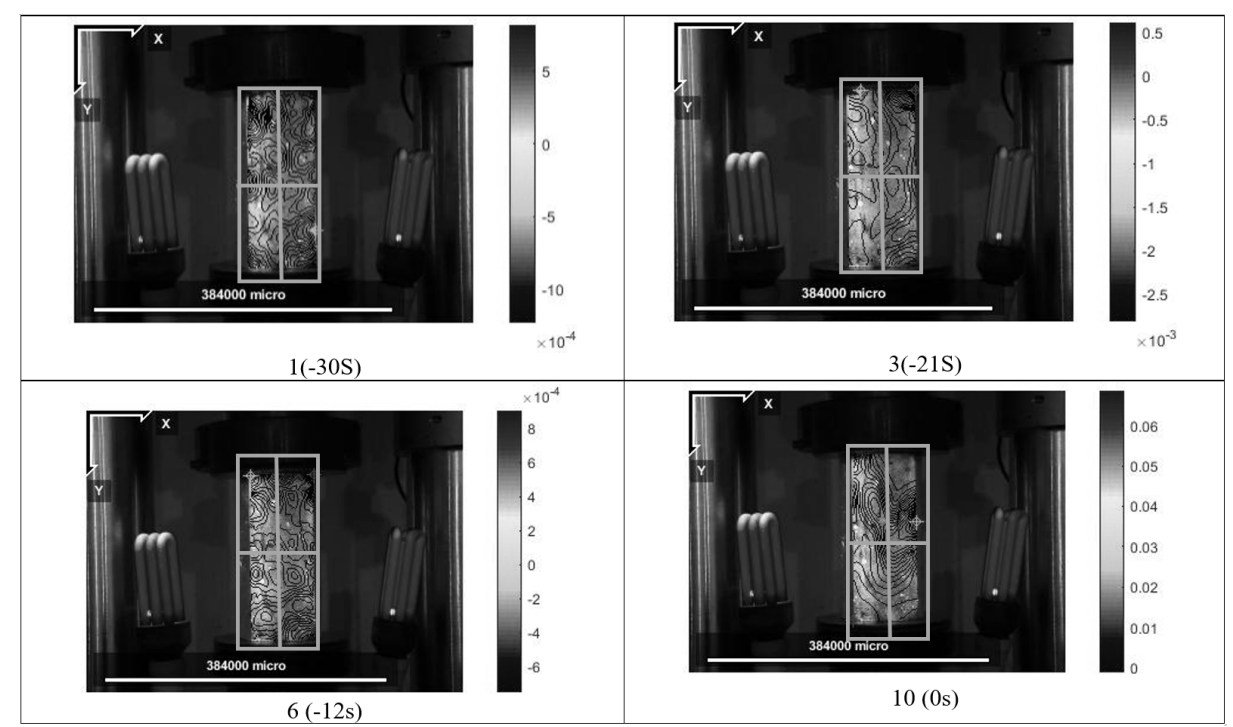

Frame 1 - Isoline map of deformations along the $\mathrm{x}$-axis.

The isoline map (Frame 1) represents the regions of specimen deformation perceived by the proposed DIC test methodology along the $\mathrm{x}$-axis, bringing us a perception of how the crack propagates during the test, in addition to the agglutination of the stress concentration points, demonstrating the phenomenon of "stress smoothing" mentioned by Carpinteri [18].

It is possible to observe through the isolines that the points of tension accumulation, tend to remain in their places, being able to agglutinate as the demands increase and the structure organizes itself for the new state of tension.

Standard 5739/2018, classifies the fracture of the specimen in seven types (Figure 7) and analyzing the distribution of the discontinuity of a PC it is possible to suggest the points of weakness.

The analysis of the deformations added to the knowledge of the type and direction of the stresses responsible for the studied deformation, arrived at the perception of the fracture prediction that will assist in a preventive action with the dynamic structural analysis including in the construction site.

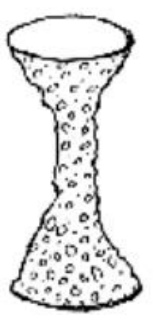

a.
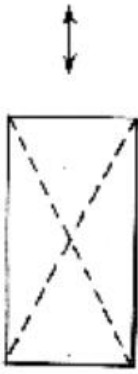

a.

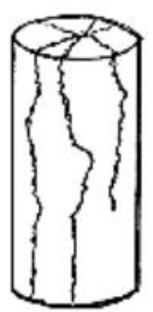

b
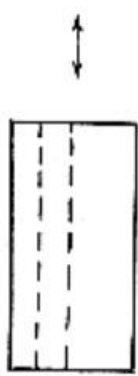

b

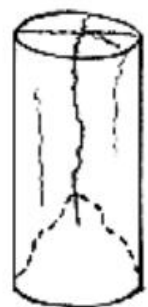

$c$
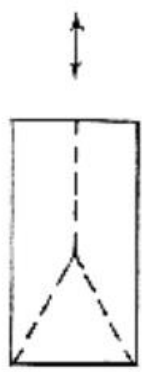

C
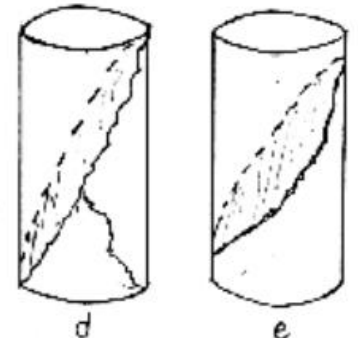

,

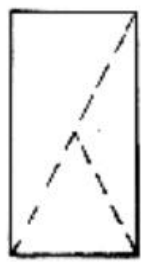

$d$

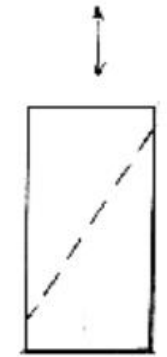

e

Figure 7 - Types of fractures provided for in NBR 5739/2018 [12]. a) conical fracture b) columnar fracture c) split columnar fracture d) sheared conical fracture e) sheared fracture. 
As shown in Figure 8, the indication of the region with fracture prediction in fields of distribution of plane $\mathrm{x}$ deformation was observed in approximately $67 \%$ of the test specimens tested.

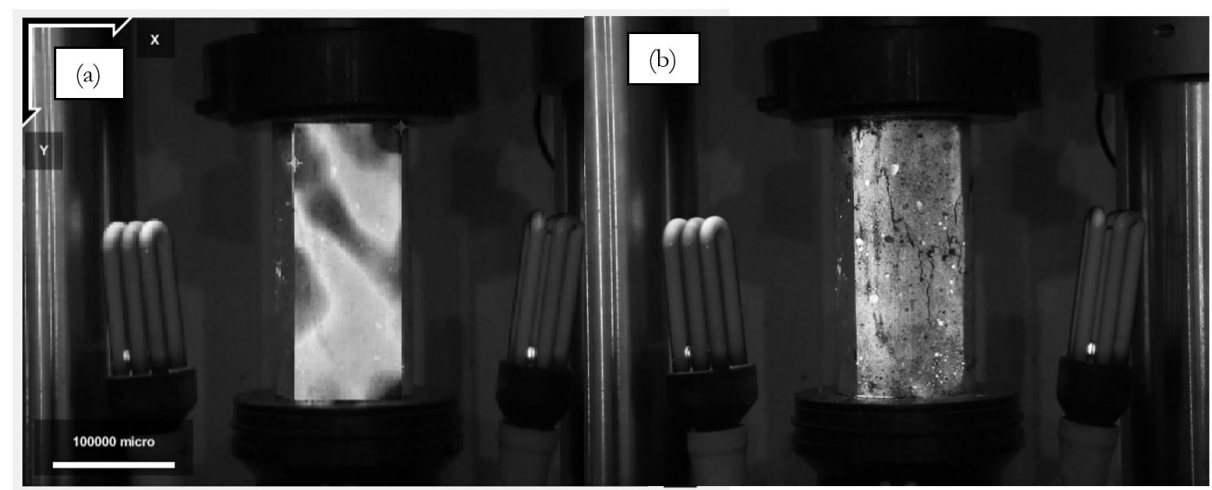

Figure 8-a) distribution of continuous deformation in the $\mathrm{x}$ plane, b) fracture of the specimen after the test

\section{CONCLUSIONS}

In the presentation of the results, it was possible to elaborate a fracture prediction map in $67 \%$ of the analyzed specimens. In the specimens where it was not possible to predict the fracture, it was observed in the images acquired when being processed, that they undergo de-correlation due to the inefficiency of the random pattern, vibrations or shading that were not controlled in the laboratory.

The map / graph prepared in this research shows that crack propagation in specimen concrete is not linear.

In the test of comparison of means of the maximum frequency observed in this test, it was possible to perceive the interdependence of transverse and axial deformations, as demonstrated by the Poisson's ratio.

The test also suggests regions of possible discontinuities through alternating points shown on the deformation map of the plane perpendicular to the application of the force.

It is also possible to notice the multiple crack propagation fronts, which change direction depending on the stress concentration points.

\section{ACKNOWLEDGEMENTS}

Author thank the State University of Santa Cruz, the Postgraduate Program in Sciences, Innovation and Modeling of Materials - PROCIMM / UESC, the Federal Institute of Bahia / Ilhéus, the Institute of Physics Armando Dias Tavares of UERJ / Rio de Janeiro, UFF / Niterói Department of Optics, UFF / Niterói Department of Mechanical Engineering, Polytechnic Institute of Rio de Janeiro - IPRJ / UERJ Nova Friburgo and AXIS Engineering.

\section{REFERENCES}

[01] M. H. F. Medeiros, J. J. O. Andrade, and P. Helene, "Durabilidade e vida útil das estruturas de concreto," in Concreto: Ciência e Tecnologia, C. Isaia, Ed., São Paulo: IBRACON, 2011.

[02] R. J. C. Ribeiro and D. R. C. Oliveira, "O colapso do edifício Real Class," Rev. IBRACON Estrut. Mater., vol. 11, no. 2, Mar/Apr 2018., http://dx.doi.org/10.1590/s1983-41952018000200008.

[03] K. Mehta and P. J. M. Monteiro, Concreto: Estrutura, Propriedades e Materiais, 3. ed. São Paulo: IBRACON, 2014.

[04] M. Koster, C. Kenel, W. J. Lee, and C. Leinenbach, "Digital image correlation for the characterization of fatigue damage evolution in brazed steel joints. 2014 Procedia," Mater. Sci., vol. 3, pp. 1117-1122, Mar. 2016.

[05] B. Pan, "Reliability-guided digital image correlation for image deformation measurement," Appl. Opt., vol. 48, pp. 1535-1542, 2009.

[06] Y. M. Picoy, "Correlação digital de imagens para medições de deslocamentos em vigas em balanço," M.S. dissertation, Engenharia de Sistemas e Automação - UFLA, Lavras, 2016.

[07] A. H. A. Santos, R. L. S. Pitangueira, G. O. Ribeiro, and R. B. Caldas, "Estudo do efeito de escala utilizando correlação de imagem digital de Imagem," Rev. IBRACON Estrut. Mater., vol. 8, no. 3, pp. 323-340, Jun 2015., http://dx.doi.org/10.1590/S1983-

41952015000300005. 
[08] O. Marques Fo. and H. Vieira No., Processamento Digital de Imagens. Rio de Janeiro: Brasport, 1999.

[09] Associação Brasileira de Normas Técnicas, NBR 5738: Moldagem e Cura de Corpos-de-Prova Cilíndricos ou Prismáticos de Concreto, 2015.

[10] W. D. Callister, Ciência e Engenharia de Materiais: Uma Introdução, 9. ed. Rio de Janeiro: John Wiley \& Sons, 2016.

[11] L. S. Assis, "Elaboração de mapa de previsão de fratura em concreto através de correlação digital de imagens DIC- 2D," Dissertação de mestrado, Universidade Estadual de Santa Cruz, Ilhéus, 2020.

[12]Associação Brasileira de Normas Técnicas, NBR 5739 Concreto - Ensaio de Compressão de Corpos de Prova Cilíndricos, 2018.

[13]F. Bárnik et al. "Measurement and comparison study of deformation using extensometer and 2D DIC technology," in 24th SlovakPolish International Scientific Conference on Machine Modelling and Simulations, Sep. 2019.

[14] J. Blaber, B. Adair, and A. Antoniou, "Ncorr: Open-Source 2D digital image correlation matlab software," SEM, vol. 55, no. 6, pp. 1105-1122, Mar. 2015.

[15] D. Corr, M. Accardi, L. Graham-Brady, and S. Shaha, "Digital image correlation analysis of interfacial debonding properties and fracture behavior in concrete," Eng. Fract. Mech., vol. 74, no. 1-2, pp. 109-121, Jan 2007.

[16]J. M. Araújo, Curso de Concreto Armado, 4. ed. Rio Grande: Dunas, 2014.

[17] N. T. Mascia, Teoria das Deformações. Campinas: Universidade Estadual de Campinas, 2017.

[18] A. Carpinteri and F. Accornero, "Multiple snap-back instabilities in progressive microcracking coalescence," Eng. Fract. Mech., vol. 187, pp. 272-281, Jan 2017., http://dx.doi.org/10.1016/j.engfracmech.2017.11.034.

Author contributions: JTA: conceptualization, supervision, writing; JRCP: conceptualization, supervision, writing; ADTJ: conceptualization

Editors: Lia Pimentel, Guilherme Aris Parsekian. 